\title{
BMJ Open Treating lateral epicondylitis with corticosteroid injections or non-electrotherapeutical physiotherapy: a systematic review
}

\author{
Morten Olaussen, ${ }^{1}$ Oeystein Holmedal, ${ }^{1}$ Morten Lindbaek, ${ }^{1}$ Soeren Brage ${ }^{2}$ \\ Hiroko Solvang ${ }^{1}$
}

To cite: Olaussen $\mathrm{M}$, Holmedal 0, Lindbaek M, et al. Treating lateral epicondylitis with corticosteroid injections or non-electrotherapeutical physiotherapy: a systematic review. BMJ Open 2013;3: e003564. doi:10.1136/ bmjopen-2013-003564

- Prepublication history for this paper is available online. To view these files please visit the journal online (http://dx.doi.org/10.1136/ bmjopen-2013-003564).

Received 9 July 2013 Revised 27 August 2013 Accepted 29 August 2013

CrossMark

\footnotetext{
${ }^{1}$ Department of General Practice, University of Oslo, Oslo, Norway

${ }^{2}$ Department of Community Health, University of Oslo, Norway
}

Correspondence to Dr Morten Olaussen; morten.olaussen@medisin. uio.no

\begin{abstract}
Objectives: To evaluate the current evidence for the efficacy of corticosteroid injection and nonelectrotherapeutic physiotherapy compared with control for treating lateral epicondylitis.

Design: Systematic review.

Participants: We searched five databases in September 2012 for randomised controlled studies with a minimum quality rating. Of the 640 studies retrieved, 11 were included, representing 1161 patients of both sexes and all ages.

Interventions: Corticosteroid injection and nonelectrotherapeutic physiotherapy.

Outcome measures: Relative risk (RR) or standardised mean difference (SMD) for overall improvement, pain and grip strength at 4-12, 26 and 52 weeks of follow-up.
\end{abstract}

Results: Corticosteroid injection gave a short-term reduction in pain versus no intervention or nonsteroidal anti-inflammatory drugs (SMD $-1.43,95 \% \mathrm{Cl}$ -1.64 to -1.23$)$. At intermediate follow-up, we found an increase in pain (SMD $0.32,95 \% \mathrm{Cl} 0.13$ to 0.51 ), reduction in grip strength (SMD $-0.48,95 \% \mathrm{Cl}-0.73$ to -0.24$)$ and negative effect on the overall improvement effect (RR 0.66 (0.53 to 0.81)). For corticosteroid injection versus lidocaine injection, the evidence was conflicting. At long-term follow-up, there was no difference on overall improvement and grip strength, with conflicting evidence for pain. Manipulation and exercise versus no intervention showed beneficial effect at short-term follow-up (overall improvement RR 2.75, 95\% Cl 1.30 to 5.82), but no significant difference at intermediate or longterm follow-up. We found moderate evidence for shortterm and long-term effects of eccentric exercise and stretching versus no intervention. For exercise versus no intervention and eccentric or concentric exercise and stretching versus stretching alone, we found moderate evidence of no short-term effect.

Conclusions: Corticosteroid injections have a shortterm beneficial effect on lateral epicondylitis, but a negative effect in the intermediate term. Evidence on the long-term effect is conflicting. Manipulation and exercise and exercise and stretching have a short-term effect, with the latter also having a long-term effect.

\section{ARTICLE SUMMARY}

Strengths and limitations of this study

- We found few good quality studies on non-electrotherapeutic physiotherapy. A meta-analysis was possible for one of the investigated treatments.

- The conclusions on the efficacy of corticosteroid injections are based on eight studies, and are strongest for short-term and intermediate-term results.

- Owing to large heterogeneity between studies, only some outcomes on corticosteroid injections were possible to pool.

- We included only studies with a control-group with no treatment and used an established quality rating scale, which strengthens the review.

\section{INTRODUCTION}

Lateral epicondylitis of the elbow is a frequently encountered complaint in general practice with an incidence of 4-7/1000/ year. ${ }^{1-3}$ It is characterised by pain and tenderness over the lateral humeral epicondyle and pain on resisted dorsiflexion and radial deviation of the wrist. It is usually a self-limiting condition, often resolving in 6-12 months regardless of treatment, but complaints may last up to 2 years or longer. ${ }^{4}$ Owing to considerable pain and discomfort, many patients need time off from work.

Most authors attribute the condition to a lesion in the short radial extensor muscle. ${ }^{15}$ A recent study has found evidence of reduced hyperaemia measured with spectral and colour Doppler in lateral epicondylitis treated with corticosteroid injection, suggesting the evidence of an inflammatory component. ${ }^{6}$ Others, finding little evidence of inflammation, have proposed the term 'lateral epicondylalgia' for the condition. ${ }^{7}$

Most patients with lateral epicondylitis are treated in general practice, and although a 
large number of treatments are in use, there is no consensus on which treatments are most effective. The Cochrane Library has reviewed several treatments. For topical nonsteroidal anti-inflammatory drugs (NSAIDs) and NSAIDs taken orally, the conclusion is that both may have a shortterm effect. ${ }^{8}$ For extracorporeal shockwave therapy, a review of nine studies including 1000 patients found this treatment to have no effect. ${ }^{9}$ For acupuncture,${ }^{10}$ deep friction massage ${ }^{11}$ orthosis ${ }^{12}$ and surgery, ${ }^{13}$ the reviews were inconclusive due to few published studies.

Four review articles have been published on the effect of corticosteroid injections. ${ }^{14-17}$ They found a short-term effect of corticosteroid injection, but no proven longterm effect, and one review found evidence of a negative long-term effect. ${ }^{15}$ However, some of the reviews included non-controlled studies ${ }^{14}{ }^{16}$ and nonrandomised studies. ${ }^{16}$ In one review, ${ }^{15} 4$ of the 12 included studies had no control group and one was a small pilot study with a short follow-up. Based on this, we find evidence in published reviews on the long-term effect of corticosteroid injections to be conflicting.

Five reviews of physiotherapeutic interventions show that there are few published studies on the effect of non-electrotherapeutic treatment, and many have methodological weaknesses. ${ }^{16}{ }^{18-21}$ Bisset et al $^{18}$ found evidence that manipulation and exercise had a short-term effect. Four other reviews ${ }^{16}{ }^{19-21}$ found short-term effects of mobilisation, manipulation and exercise. Three of these reviews included non-randomised or noncontrolled studies. ${ }^{16} 1921$ Most previous systematic reviews have included electrotherapeutic physiotherapy such as ultrasound and extracorporeal shockwave. ${ }^{14162021}$

Since there is no established, well-documented treatment to which new treatments can be compared, the use of a control group is important. The natural course of the condition, where most patients eventually recover regardless of the intervention, makes this even more necessary. In a comparison of two different treatments, any effect found may only reflect this natural course of recovery unless the treatments prove better than a control group with no treatment.

It has been shown that systematic reviews which include studies with low scores on internal validity may overestimate effect sizes, thus introducing a potential bias to the review. ${ }^{22}$ There may also be a problem using rating scales with heterogeneous criteria, including that is, criteria related to external validity, interpretation or ethical issues. 2223

To address these issues, a new systematic review on non-electrotherapeutic physiotherapy and corticosteroid injection seemed warranted. We wanted to include only randomised studies with a control group with no treatment or studies in which the groups only differed in regard to the investigated treatment. An established quality rating scale would be used. We also wanted to review the most current evidence on the efficacy of corticosteroid injections, since previous reviews have differing conclusions on the long-term effect.

\section{Objective}

The aim of this review was to assess the current evidence for the efficacy of corticosteroid injections and non-electrotherapeutical physiotherapy compared with control in patients with tennis elbow.

\section{METHODS}

We followed the recommendations of the Cochrane Collaboration $^{24}$ and the PRISMA Group ${ }^{25}$ in the search and report of this systematic review.

\section{Study selection}

We used the following inclusion criteria.

\section{Study type}

Randomised controlled trials assessing treatments for lateral epicondylitis or tennis elbow were eligible for inclusion. The studies had to have at least one treatment group and one control group. We defined a control group as a group receiving no treatment (a wait-and-see approach), common treatments with expected or known moderate effect (advice, rest, NSAIDs, painkillers) or the same treatment as the experimental group with the exception of the investigated treatment.

\section{Participants}

All age groups with a clinical diagnosis of lateral epicondylitis were included without restriction on the gender.

\section{Treatments}

We searched for studies investigating or comparing the efficacy of one of the following treatments: corticosteroid injection, non-electrotherapeutic physiotherapy including stretching, mobilisation, manipulation, massage, exercise or home training. Studies on the splinting, ultrasound, shock wave and other electrotherapeutic modalities were excluded.

\section{Outcome measures and follow-up}

At least one validated, patient-centred outcome was necessary. This could include outcomes important to the patient, such as pain, range of movement, grip strength, work status and relevant functional questionnaires. We included only studies carried out in a clinical setting with at least a 4-week follow-up of the treatment effect.

\section{Study quality assessment}

We used the 11-item Physiotherapy Evidence Database (PEDro) scale to assess the quality of the studies included in the review. This rating system closely resembles the Cochrane Collaboration Scoring system ${ }^{24}$ and is based on the Delphi list, developed for quality assessment of randomised controlled trials (RCTs) by Verhagen $e t a l^{26}$ It has been used in several previously published reviews. ${ }^{15} 1819$ The PEDro scale assesses the internal and external validity of a study by addressing 
the issues of eligibility criteria, randomisation, allocation, blinding, statistics and data reporting. The reliability of this scale has been confirmed by Maher et al. ${ }^{27}$. The maximum score is 10 , since item number 1 on the scale (specified eligibility criteria) is not counted.

A minimum score of $5 \mathrm{t}$ of 10 points $(50 \%)$ was chosen to be necessary for inclusion in the review, as inclusion of lower quality studies in a systematic review may overestimate the treatment effect of interventions. ${ }^{28}$ Ten studies were independently assessed by two researchers $(\mathrm{MO} \text { and } \varnothing \mathrm{H})^{29-38}$ and three studies were rated by both researchers together. ${ }^{39-41}$ The final decision on the PEDro score was reached by consensus.

\section{Search methods for identification of studies Electronic searches}

From October 2009 to January 2010, we searched the following databases for publications: MEDLINE (Ovid and PubMed), EVSCO/CINAHL, EMBASE, Allied and Complimentary Medicine, PEDro and the Cochrane RCT register. The searches within each database were carried out without restrictions on dates or languages. We used free text, not MESH terms, in these searches, and the key terms used were 'tennis elbow', 'lateral epicondylitis', epicondylalgia, elbow, randomised, injection, corticosteroid and physiotherapy. The Boolean operator AND was used to link diagnostic terms and treatment where applicable. An additional search was carried out in September 2012 to identify any recently published studies.

\section{Searching other resources}

Further search was carried out in the reference list of articles initially considered for review.

\section{Selection of studies}

The searches resulted in a number of studies potentially eligible for inclusion. Titles and abstracts were then read by two researchers independently (MO and $\varnothing \mathrm{H})$ and potential studies were selected based on the inclusion criteria. The final decision on inclusion was made by consensus from a reading of the full-text documents.

\section{Data extraction and statistical analysis}

The included studies were read in full text and assessed by two independent researchers (MO and $\varnothing \mathrm{H})$. One article, published in Italian, was translated by a professional bureau. ${ }^{41}$ A standardised set of data was extracted from each selected study and recorded using standardised forms. We calculated statistics using the statistical computing language $\mathrm{R}$ (http://www.r-project.org, The $\mathrm{R}$ Foundation for Statistical Computing, Vienna, Austria). We reported the results of the outcome measures for three different timings of follow-up, defined as short term (4-12 weeks after randomisation), intermediate term (6 months after randomisation) and long term (more than 6 months after randomisation). For dichotomous data, we calculated relative risk (RR) and $95 \%$ CI with the R-project library 'epi.R', for continuous data, the standardised mean difference (SMD) and 95\% CI with the R-project library 'compute.es'. We pooled estimates when we found sufficient clinical and statistical homogeneity between trials using the $\mathrm{I}^{2}$ statistic, defined as $\mathrm{I}^{2}$ less than $65 \%{ }^{42}$

Some studies did not report the mean, SD or number of samples, which were necessary to calculate SMD. Additional calculations were then required. For Coombes ${ }^{38}$ the median and the IQR were given. We set the median as the mean value and the SD was given by $\mathrm{IQR} / 1.35$ under the assumption of normal distribution. For Newcomer, ${ }^{33}$ SD was calculated by the t-statistics obtained by the $\mathrm{p}$ value and degrees of freedom. For Price $e t a l,{ }^{34}$ the t-statistics were obtained by the degrees of freedom and $95 \%$ probability. SD was estimated by the t-statistics, the mean value and the upper/lower CIs.

For overall improvement, an RR larger than 1 favoured treatment and was statistically significant if the CI excluded 1. We defined the effect as large for values larger than 2 or less than 0.5 , medium between 0.5 and 0.8 and between 1.25 and 2 and small for values between 0.8 and 1.0 and between 1.0 and 1.25.

For continuous data, a positive or negative SMD favoured treatment depending on the outcome measures, that is, for pain, a negative SMD favoured treatment and for grip strength a positive SMD favoured treatment. SMD was statistically significant if the CI excluded 0 . We defined the effect as large for SMD more than 0.8 , medium between 0.5 and 0.8 and small for values less than 0.5. For outcomes that could not be pooled, we graded the strength of the scientific evidence as strong (consistent findings in several high quality randomised controlled studies), moderate (one high quality randomised controlled study), conflicting (inconsistent finding between many studies) or no evidence. ${ }^{43}$

\section{Inter-rater reliability}

The inter-rater reliability for the individual PEDro scores was assessed by calculating the intraclass correlation coefficient. ${ }^{44}$ The R-project library 'psych' was used for this calculation. A substantial inter-rater reliability was found (intraclass correlation coefficient 0.69 (0.15$0.91), \mathrm{p}<0.01)$.

\section{RESULTS}

The search retrieved an initial 839 hits, representing 640 individual articles. The further selection process is outlined in figure 1. Six hundred and twenty-three articles were excluded based on the title and abstract in a preliminary review. Seventeen articles ${ }^{29-37} 3941 \quad 45-50$ were then assessed using the full-text documents. Three were found not to be RCTs, ${ }^{45-47}$ two had a PEDro quality rating below $50 \%$ (table 2$)^{37} 39$ and three had a follow-up shorter than 4 weeks. ${ }^{4-50}$ The additional search carried out in September 2012 retrieved two possible studies, ${ }^{40} 51$ one of which was excluded for not 


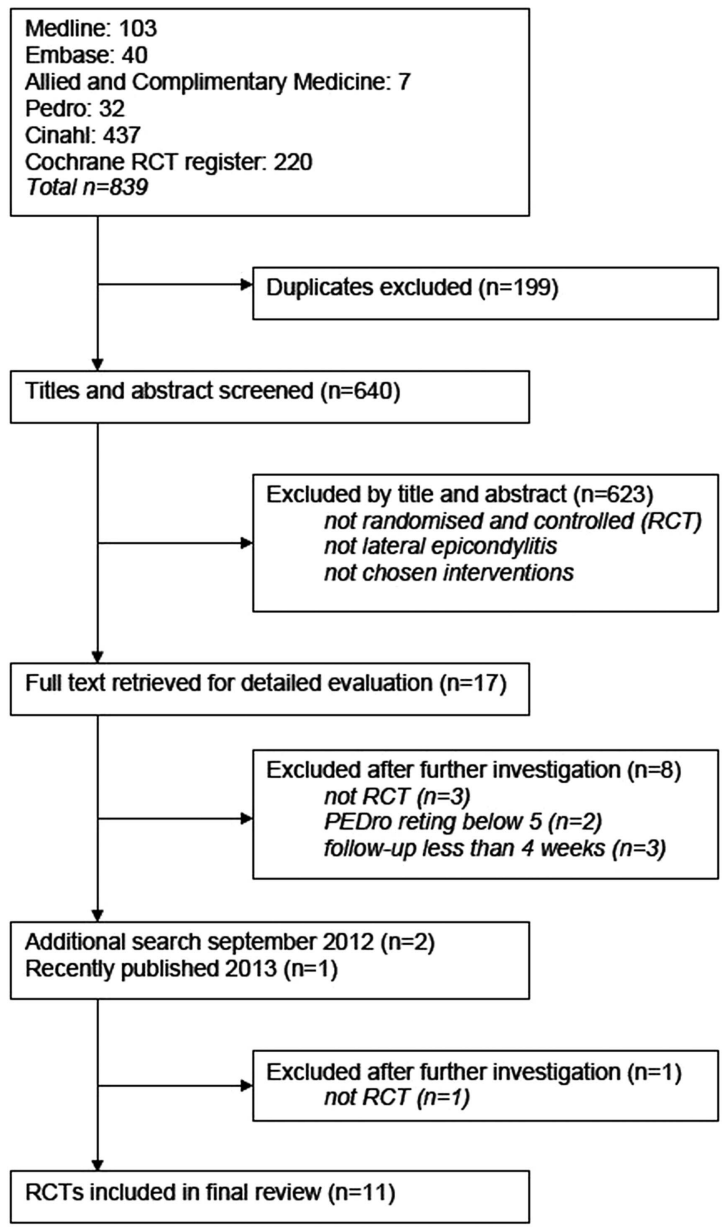

Figure 1 Outline of the selection process.

having a control group. ${ }^{51}$ A recently published study was also assessed ${ }^{38}$ and a total of 11 studies were included in the final review. ${ }^{29-36} 384041$

\section{Included studies}

The characteristics and details of each study are given in table 1 . The included studies represented a total population of 1161 patients. Several studies had more than one treatment group, so the 11 included studies investigated 15 treatment groups relevant for this review. For the statistical analysis, one study, which used two different corticosteroids, was treated as two studies. ${ }^{34}$

The mean age of patients varied from 41 to 51 years and the female percentages varied from 35 to 63 . There were large differences in the duration of complaints at baseline between studies. Most had a duration of several weeks to months and only one stated a short duration. ${ }^{33}$ Eight studies had control groups with no active treatment, ${ }^{29-31}$ 34-36 38 40 for example, a wait-and-see group or NSAIDs. Two of these used lidocaine as a placebo injection. ${ }^{31}{ }^{34}$ In the three other studies, the control and treatment groups both received similar active treatments, with the intervention group additionally receiving the treatment to be investigated. ${ }^{32} 3341$
Eight studies investigated corticosteroid injections, representing 925 patients. ${ }^{29-31}$ 33-36 38 Five different corticosteroids were used, with different dosages and injection techniques. The control groups received no active treatment in seven of the eight studies, whereas in one study the control and the treatment groups received additional exercise treatment. ${ }^{33}$ Seven of the studies had a long-time follow-up of 24 weeks or more. $.^{29-31} 33-3538$

There were few studies covering non-electrotherapeutic physiotherapy. We found five studies which could be included, representing 600 patients. ${ }^{29} 32384041$ The treatment modalities investigated were manipulation and exercise, ${ }^{29} 38$ concentric or eccentric exercises, ${ }^{32}$ and exercise $^{40}$ and eccentric exercises with stretching. ${ }^{41}$ Three studies had a control group with no active treatment, ${ }^{29} 3840$ whereas the other two had control groups that received stretching and orthosis, respectively. Three studies $^{29} 3841$ had a follow-up of 24 weeks or more.

The most frequently used outcome measures were assessment of pain and grip strength. Six studies measured pain-free grip strength with hand-held dynamometers. ${ }^{29-33} 35$ Eight studies used a number of different questionnaires covering pain, function and disability. ${ }^{29-33} 353840$ Nine studies assessed pain on a visual analogue scale or Likert scale, ${ }^{29-34} 363840$ and six studies rated the patient's assessment of improvement on graded scales. ${ }^{29} 3035363841$

\section{Risk of bias in included studies}

We addressed the issues of the quality of the included studies and completeness of reported data by rating them with the PEDro scale (table 2). Most studies used a computerised randomisation schedule, and 7 of the 11 studies used concealed allocation. ${ }^{29-31} \quad 35 \quad 38 \quad 40 \quad 41$ Baseline comparison was carried out in all studies, the dropout rate was below $15 \%$ in 10 studies ${ }^{29} \quad 30 \quad 32-$ 36384041 and intention-to-treat analysis was stated in all studies. There was between-group analysis of at least one outcome measure in all the studies, and both point measures and variations of outcome measures were reported in all studies.

The use of blinding was more diverse among the studies. Blinding the patient for treatment is difficult for physiotherapeutic treatments, but the use of blinded assessors reduces the risk of bias. None of the studies on physiotherapy in our review had blinded patients or therapists, but two used blinded assessors. ${ }^{29} 38$ This might give biased results in the studies covering physiotherapeutic treatments.

For the eight studies on corticosteroid injection, the number using blinding was larger. There was blinding of patients in four studies, ${ }^{31} 333438$ of the treating doctor in two studies ${ }^{31} 33$ and of assessors in six studies. ${ }^{29-31} 343538$

In several studies, the control group received some form of treatment (similar to the treatment group).$^{32-34} 3641 \mathrm{In}$ these studies, synergistic effects between the treatments cannot be ruled out. This makes the results more difficult 
Table 1 Demographics, treatments and outcome measures in the eleven included studies

\begin{tabular}{|c|c|c|c|c|c|c|c|}
\hline $\begin{array}{l}\text { Study and } \\
\text { year setting } \\
\text { and sample } \\
\text { size }\end{array}$ & $\begin{array}{l}\text { Women } \\
\text { (percentages) }\end{array}$ & $\begin{array}{l}\text { Age (mean if not } \\
\text { otherwise stated) }\end{array}$ & $\begin{array}{l}\text { Duration of } \\
\text { discomforts } \\
\text { (weeks) }\end{array}$ & Treatment groups & Control group & $\begin{array}{l}\text { Outcome measures } \\
\text { (excerpts) }\end{array}$ & $\begin{array}{l}\text { Follow-up } \\
\text { (weeks) }\end{array}$ \\
\hline $\begin{array}{l}\text { Bisset et al } \\
2006 \\
\text { Outpatient clinic } \\
n=198\end{array}$ & 35 & 47.6 (SD 7.8) & $\begin{array}{l}22 \text { (median) } \\
\text { (IQR 12-42) }\end{array}$ & $\begin{array}{l}\text { (1) } 10 \text { mg Triamcinolone and } \\
1 \mathrm{~mL} \text { lidocaine against the most } \\
\text { painful point repeated after } \\
2 \text { weeks } \\
\text { (2) Elbow manipulation } \\
\text { (manipulation with movement) } \\
\text { and exercise } \\
8 \text { sessions of } 30 \text { min duration } \\
\text { during a } 6 \text { week period and } \\
\text { home exercise }\end{array}$ & $\begin{array}{l}\text { Information, } \\
\text { wait-and-see }\end{array}$ & $\begin{array}{l}\text { Improvement on } \\
\text { 6-point Likert-scale } \\
\text { PFGS assessed } \\
\text { severity on VAS } \\
\text { Pain on VAS } \\
\text { Pain-free function } \\
\text { questionnaire }\end{array}$ & 52 \\
\hline $\begin{array}{l}\text { Coombes et al } \\
2013 \\
\text { Community } \\
\text { setting } n=165\end{array}$ & 38 & 49.7 (SD 8.1) & $\begin{array}{l}16 \text { (median) } \\
\text { (IQR 10-26) }\end{array}$ & $\begin{array}{l}\text { (1) One injection of } 1 \mathrm{~mL} \\
\text { triamcinolone } 10 \mathrm{~mL} / \mathrm{mL} \text { and } \\
1 \mathrm{~mL} \text { lignocaine } 1 \% \text { against site } \\
\text { of greatest palpable tenderness } \\
\text { at the common extensor origin } \\
\text { (2) Elbow manipulation } \\
\text { (manipulation with movement) } \\
\text { and exercise } \\
8 \text { sessions of } 30 \text { min duration } \\
\text { during a } 8 \text { week period and } \\
\text { home exercise } \\
\text { (3) One injection of } \\
\text { triamcinolone followed by } 8 \\
\text { sessions of elbow manipulation } \\
\text { and exercise, home exercise for } \\
8 \text { weeks (not considered in this } \\
\text { review) }\end{array}$ & $\begin{array}{l}\text { Placebo injection } \\
0.5 \mathrm{~mL} 0.9 \% \text { isotonic } \\
\text { saline }\end{array}$ & $\begin{array}{l}\text { Improvement on } \\
6 \text {-point Likert-scale } \\
1 \text { year recurrence } \\
\text { Pain on VAS } \\
\text { PRTEE questionnaire } \\
\text { EuroQol-EQ-5D } \\
\text { quality-of-life score }\end{array}$ & 52 \\
\hline $\begin{array}{l}\text { Hay et al } 1999 \\
\text { General } \\
\text { practice } n=164\end{array}$ & $\begin{array}{l}\text { Group 1:41 } \\
\text { (Group 2:53) } \\
\text { Control:48 }\end{array}$ & $\begin{array}{l}\text { Age } \geq 45: \\
\text { (percentages) } \\
\text { Group 1:70 } \\
\text { (Group 2:68) } \\
\text { Control:38 }\end{array}$ & $\begin{array}{l}9 \text { (mean) } \\
\text { Percentage with } \\
\text { pain >3 months: } \\
\text { Group 1:36 } \\
\text { (Group 2:25) } \\
\text { Control:31 }\end{array}$ & $\begin{array}{l}\text { (1) One injection of } \\
\text { methylprednisolone } 20 \mathrm{mg} \text { and } \\
0.5 \mathrm{~mL} 1 \% \text { lignocaine towards } \\
\text { tender spot } \\
\text { (2) Naproxen orally } 500 \mathrm{mg} \\
\text { twice daily for } 2 \text { weeks (not } \\
\text { considered in this review) }\end{array}$ & Placebo tablets & $\begin{array}{l}\text { Improvement on } \\
\text { 5-point Likert-scale } \\
\text { Pain on 10-point } \\
\text { Likert-scale } \\
\text { Function on 10-point } \\
\text { Likert-scale } \\
\text { Main discomfort on } \\
\text { 10-point Likert-scale } \\
\text { Disability } \\
\text { questionnaire } \\
\text { PFGS }\end{array}$ & 52 \\
\hline
\end{tabular}




\begin{tabular}{|c|c|c|c|c|c|c|c|}
\hline $\begin{array}{l}\text { Study and } \\
\text { year setting } \\
\text { and sample } \\
\text { size }\end{array}$ & $\begin{array}{l}\text { Women } \\
\text { (percentages) }\end{array}$ & $\begin{array}{l}\text { Age (mean if not } \\
\text { otherwise stated) }\end{array}$ & $\begin{array}{l}\text { Duration of } \\
\text { discomforts } \\
\text { (weeks) }\end{array}$ & Treatment groups & Control group & $\begin{array}{l}\text { Outcome measures } \\
\text { (excerpts) }\end{array}$ & $\begin{array}{l}\text { Follow-up } \\
\text { (weeks) }\end{array}$ \\
\hline $\begin{array}{l}\text { Price et al } 1991 \\
\text { Outpatient clinic } \\
n=88\end{array}$ & $\begin{array}{l}\text { Group 1:48 } \\
\text { Group 2:43 } \\
\text { Control:38 }\end{array}$ & $\begin{array}{l}\text { Group 1:47 } \\
\text { Group 2:47 } \\
\text { Control:46 } \\
\text { (Median) }\end{array}$ & $\begin{array}{l}\text { Group 1:20 (6- } \\
\text { 150) } \\
\text { Group 2:36 (6- } \\
\text { 154) } \\
\text { Control:16 (6-150) } \\
\text { (Median and } \\
\text { range) }\end{array}$ & $\begin{array}{l}\text { (1) Hydrocortisone } 25 \mathrm{mg} \text { and } \\
1 \% \text { lidocaine against tender } \\
\text { point ( } 2 \mathrm{~mL} \text { fluid) }(55 \% \text { received } \\
2 \text { injections) } \\
\text { (2) Triamcinolone } 10 \mathrm{mg} \text { and } \\
1 \% \text { lidocaine ( } 30 \% \text { received } \\
\text { two injections) }\end{array}$ & $\begin{array}{l}2 \mathrm{~mL} 1 \% \text { lidocaine } \\
\text { against tender point }\end{array}$ & $\begin{array}{l}\text { Pain on VAS } \\
\text { Tenderness score } \\
\text { Pain-weighted grip } \\
\text { strength }\end{array}$ & 24 \\
\hline $\begin{array}{l}\text { Smidt et al } \\
2002 \\
\text { General } \\
\text { practice } \mathrm{n}=185\end{array}$ & $\begin{array}{l}\text { Group 1:55 } \\
\text { (Group 2:44) } \\
\text { Control: } 53\end{array}$ & $\begin{array}{l}\text { Group 1: } 47 \\
\text { (Group 2:48) } \\
\text { Control: } 46 \\
\text { (Median) }\end{array}$ & $\begin{array}{l}\text { Group 1:11 (8-16) } \\
\text { (Group 2:11 (8- } \\
21) \text { ) } \\
\text { Control:11 (8-21) } \\
\text { (Median and IQR) }\end{array}$ & $\begin{array}{l}\text { (1) } 10 \mathrm{mg} \text { triamcinolone and } \\
1 \mathrm{~mL} \text { lidocain against all tender } \\
\text { points up to three injections } \\
\text { (2) One group received } \\
\text { physiotherapy with ultrasound } \\
\text { (not considered in this review) }\end{array}$ & $\begin{array}{l}\text { Wait-and-see (some } \\
\text { were prescribed } \\
\text { naproxen orally } \\
1000 \mathrm{mg} \text { daily) }\end{array}$ & $\begin{array}{l}\text { Improvement on } \\
\text { 6-point Likert scale } \\
\text { Severity of discomfort } \\
\text { on scale } \\
\text { Questionnaires } \\
\text { PFGS } \\
\text { Maximum grip } \\
\text { strength (MGS) } \\
\text { Pressure-pain } \\
\text { measurements } \\
\text { Satisfaction with } \\
\text { treatment }\end{array}$ & 52 \\
\hline $\begin{array}{l}\text { Toker et al } \\
2008 \\
\text { Outpatient clinic } \\
\mathrm{n}=21\end{array}$ & 43 & 45 (range 19-72) & Not stated & $\begin{array}{l}\text { One injection of } 1 \mathrm{~mL} \\
\text { metylprednisolon and } 1 \mathrm{~mL} \\
\text { prilocain with oral diklofenac } \\
\text { three tablets (dose not stated) } \\
\text { and etofenamate topically }\end{array}$ & $\begin{array}{l}\text { Oral diklofenac three } \\
\text { tablets (dose not } \\
\text { stated) and } \\
\text { etofenamate topically }\end{array}$ & $\begin{array}{l}\text { Perceived absence of } \\
\text { pain } \\
\text { Absence of pain on } \\
\text { palpation over lateral } \\
\text { epicondyle and on } \\
\text { isometric dorsiflection } \\
\text { of wrist pain score }\end{array}$ & 4 \\
\hline $\begin{array}{l}\text { Lindenhovius } \\
\text { et al } 2008 \\
\text { Outpatient clinic } \\
\mathrm{n}=64\end{array}$ & $\begin{array}{l}\text { Treatment: } 63 \\
\text { Control: } 60\end{array}$ & $\begin{array}{l}\text { Treatment: } 50 \pm 8 \\
\text { Control: } 51 \pm 10\end{array}$ & $\begin{array}{l}\text { Treatment: } 12 \pm 4 \\
(2-20) \\
\text { Control: } 8 \pm 4(1-20)\end{array}$ & $\begin{array}{l}4 \text { mg dexamethasone and } \\
10 \text { mg lidocaine ( } 2 \mathrm{~mL} \text { fluid) } \\
\text { against the most tender spot, } \\
\text { fanning of the needle. One } \\
\text { injection-but } 6 \text { of } 64 \text { got } 2 \\
\text { injections }\end{array}$ & $\begin{array}{l}10 \mathrm{mg} \text { lidocain, } 2 \mathrm{~mL} \\
\text { fluid total }\end{array}$ & $\begin{array}{l}\text { DASH questionnaire* } \\
\text { Pain on VAS } \\
\text { Grip strength }\end{array}$ & 26 \\
\hline $\begin{array}{l}\text { Newcomer et al } \\
2001 \\
\text { Outpatient clinic } \\
\mathrm{n}=39\end{array}$ & 51 & $\begin{array}{l}\text { Treatment: } \\
46.0 \pm 7.0 \\
\text { Control: } 44.6 \pm 7.6\end{array}$ & $\begin{array}{l}\text { Treatment: } 3.2 \\
\text { (mean) SD } 0.8 \\
\text { Control: } 3.4 \text { (mean) } \\
\text { SD } 0.9\end{array}$ & $\begin{array}{l}\text { One injection of } 5 \mathrm{~mL} 4: 1 \\
0.25 \% \text { bupivacaine and } 6 \mathrm{mg} / \\
\mathrm{mL} \beta \text {-methasone against tender } \\
\text { point. Home exercises } \\
\text { consisting of ice massage, wrist } \\
\text { stretching and progressive }\end{array}$ & $\begin{array}{l}\text { Placeboinjection of } \\
5 \mathrm{~mL} \text { bupivacaine } \\
\text { Home exercises } \\
\text { consisting of ice } \\
\text { massage, wrist } \\
\text { stretching and } \\
\text { progressive eccentric }\end{array}$ & $\begin{array}{l}\text { Pain on VAS } \\
\text { Functional pain } \\
\text { questionnaire (PFGS } \\
\text { at } 4 \text { and } 8 \text { weeks) }\end{array}$ & 26 \\
\hline
\end{tabular}




\begin{tabular}{|c|c|c|c|c|c|c|c|}
\hline $\begin{array}{l}\text { Study and } \\
\text { year setting } \\
\text { and sample } \\
\text { size }\end{array}$ & $\begin{array}{l}\text { Women } \\
\text { (percentages) }\end{array}$ & $\begin{array}{l}\text { Age (mean if not } \\
\text { otherwise stated) }\end{array}$ & $\begin{array}{l}\text { Duration of } \\
\text { discomforts } \\
\text { (weeks) }\end{array}$ & Treatment groups & Control group & $\begin{array}{l}\text { Outcome measures } \\
\text { (excerpts) }\end{array}$ & $\begin{array}{l}\text { Follow-up } \\
\text { (weeks) }\end{array}$ \\
\hline & & & & $\begin{array}{l}\text { eccentric and concentric } \\
\text { exercises }\end{array}$ & $\begin{array}{l}\text { and concentric } \\
\text { exercises }\end{array}$ & & \\
\hline $\begin{array}{l}\text { M-Silvestrini } \\
\text { et al } 2005 \\
\text { Outpatient clinic } \\
\mathrm{n}=94\end{array}$ & 47 & $45.5 \pm 7.7$ & More than 12 & $\begin{array}{l}\text { (1) Concentric strengthening } \\
3 \times 10 \text { repetitions once daily and } \\
\text { wrist stretching twice daily for } \\
6 \text { weeks } \\
\text { (2) Eccentric strengthening } \\
3 \times 10 \text { repetitions once daily and } \\
\text { wrist stretching twice daily for } \\
6 \text { weeks }\end{array}$ & $\begin{array}{l}\text { Wrist stretching twice } \\
\text { daily for } 6 \text { weeks }\end{array}$ & $\begin{array}{l}\text { PFGS } \\
\text { Pain on VAS } \\
\text { PRFEQ questionnaire } \\
\text { Patient's log of training } \\
\text { DASH questionnaire* }\end{array}$ & 6 \\
\hline $\begin{array}{l}\text { Peterson et al } \\
2011 \\
\text { General } \\
\text { practice } \mathrm{n}=81\end{array}$ & 42 & 48 & $\begin{array}{l}\text { Treatment: } 107 \\
\text { Control: } 96\end{array}$ & $\begin{array}{l}\text { Three-month daily exercise } \\
\text { regime performed at home with } \\
\text { progressively increasing load } \\
\text { on the extensor muscles }\end{array}$ & $\begin{array}{l}\text { Information, } \\
\text { wait-and-see }\end{array}$ & $\begin{array}{l}\text { Pain on VAS during } \\
\text { contraction and during } \\
\text { elongation of forearm } \\
\text { muscles } \\
\text { Muscle strength with } \\
\text { hand-held } \\
\text { dynamometer } \\
\text { DASH questionnaire }\end{array}$ & 12 \\
\hline $\begin{array}{l}\text { Selvanetti et al } \\
2003 \\
\text { Setting not } \\
\text { stated } n=62\end{array}$ & $\begin{array}{l}\text { Treatment: } 45 \\
\text { Control: } 48\end{array}$ & $\begin{array}{l}\text { Treatment: } 41.3 \\
\text { Control: } 40.5\end{array}$ & $\begin{array}{l}\text { Treatment: } 28(8- \\
40) \\
\text { Control: } 29(12-44)\end{array}$ & $\begin{array}{l}4 \text { weeks home-exercise after } \\
\text { instruction from physiotherapist } \\
\text { consisting of stretching and } \\
\text { eccentric exercise } \\
\text { Counselling and use of elbow } \\
\text { support }\end{array}$ & $\begin{array}{l}\text { Sham ultrasound } 20 \\
\text { sessions } \\
\text { Counseling and use of } \\
\text { elbow support }\end{array}$ & $\begin{array}{l}\text { Ko scoring system } \\
\text { (includes clench test, } \\
\text { Thomsen test and } \\
\text { pain) } \\
\text { Verhaar scoring } \\
\text { system on global } \\
\text { improvement } \\
\text { Subjective } \\
\text { improvement VAS } \\
\text { scale }(0-100)\end{array}$ & $44(24-56)$ \\
\hline
\end{tabular}

${ }^{*} \mathrm{DASH}$ questionnaire is an upper extremity specific health status measure.

DASH,Disability of the Arm, Shoulder and Hand; PFGS, Pain-Free Grip Strength;PRFEQ, Patient-rated Forearm Evaluation Questionnaire; PRTEE questionnaire, Patient-Rated Tennis Elbow Score, VAS, Visual Analogue Scale. 
Table 2 Quality rating of studies by assessing internal and external validity with the PEDro scale

Study PEDro criterion Bisset Coombes Hay Price Smidt Toker Lindenhovius Newcomer M-Silvestrini Peterson Selvanetti Kochar

1 Eligibility criteria were specified

2 Participants were randomly allocated to groups

3 Allocation was concealed

1

The groups were similar at baseline regarding the most important prognostic indicators

5 There was blinding of all participants

6 There was blinding of all 0 therapists who administered the therapy

7 There was blinding of all 1 assessors who

measured at least one key outcome

8 Measures of at least one key outcome were obtained from more than $85 \%$ of the participants initially allocated to groups

9 All participants for whom outcome measures were available, received the treatment or control condition as allocated or, where this was not the case, data for at least one key outcome was analysed by 'intention to treat' 


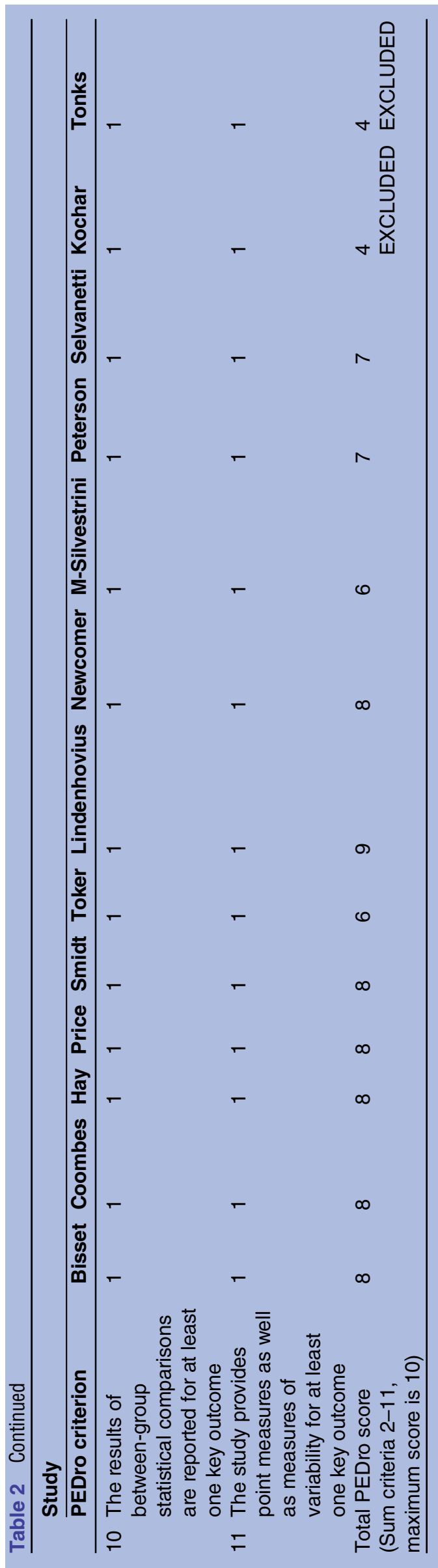

to interpret. Two studies had a short follow-up of 4 and 6 weeks, ${ }^{32} 36$ which for a condition usually lasting several months reduces the clinical implication of the results. The difference in duration of complaints at baseline also complicates comparison between studies.

\section{Effects of interventions}

\section{Corticosteroid injection}

The efficacy of corticosteroid injections for treating lateral epicondylitis was investigated in eight studies (table 3 and figure $2^{52}$ ). For short-term follow-up, the heterogeneity between studies made pooling of outcomes possible only for pain. For corticosteroid injection versus no intervention or NSAIDs, we found strong evidence for a beneficial effect on overall improvement and a large positive effect on pain. ${ }^{29} 30 \quad 353638$ For grip strength, we found moderate evidence for a negative effect. ${ }^{35}$ For corticosteroid injection versus lidocaine injection, evidence was conflicting for effect on pain, with two studies showing a large positive effect (Price $e t a l^{34}$ using hydrocortisone and triamcinolone) and one showing no significant difference. ${ }^{31}$ For maximum grip strength, the evidence was also conflicting, with one study showing a large positive effect of treatment (Price et $a l^{34}$ using triamcinolone), and two studies showing no statistical difference (Lindenhovius $e t a l^{31}$, Price $e t a l^{34}$ using hydrocortisone). For corticosteroid injection, exercise and stretching versus exercise and stretching alone, we found moderate evidence for no significant difference on pain and grip strength. $^{33}$

At intermediate follow-up, we found sufficient homogeneity to pool estimates for overall improvement ${ }^{29} 3038$ and pain ${ }^{29} 303538$ for corticosteroid injection versus no intervention or NSAIDs. For overall improvement, this showed a medium negative effect and for pain, a small negative effect. For maximum grip strength, pooling of corticosteroid injection versus no intervention, NSAIDS and lidocaine showed a small negative effect. ${ }^{31} 3435$ For corticosteroid injection versus lidocaine injection, pooling of estimates was not possible due to heterogeneity. For pain, two studies showed a large negative effect (Price $e t a b^{4}$ using hydrocortisone and triamcinolone), and one study showed no significant difference; ${ }^{31}$ thus, the evidence was conflicting. For grip strength, the evidence was also conflicting, with the same two studies showing a large negative effect ${ }^{34}$ and one showing no significant difference. $^{31}$ For corticosteroid injection, exercise and stretching versus exercise and stretching alone, we found moderate evidence of no significant effect on pain. ${ }^{33}$

At long-term follow-up, pooled estimates of overall improvement showed no difference in the effect of corticosteroid injection versus no intervention or NSAIDs. $^{29} 30 \quad 3538$ For pain, heterogeneity prevented pooling and we found the evidence conflicting with one study showing a large negative effect, ${ }^{30}$ and three others showing no significant difference in effect. ${ }^{29} 3538$ For 
Table 3 Effect size of improvement rate, reduction in pain and increase in grip strength for corticosteroid injection

$\begin{array}{lll}\text { Short term } & \text { Intermediate term } & \text { Long term } \\ 4-12 \text { weeks } & 26 \text { weeks } & 52 \text { weeks }\end{array}$

\begin{tabular}{|c|c|c|c|}
\hline \multicolumn{4}{|c|}{ Overall improvement $R R(95 \% \mathrm{Cl}) R R>1$ favours treatment } \\
\hline Bisset & $2.94(1.90 \text { to } 4.45)^{*}$ & $0.55(0.41 \text { to } 0.73)^{*}$ & $0.75(0.62 \text { to } 0.90)^{\star}$ \\
\hline Coombes & $7.32(2.83 \text { to } 18.94)^{\star}$ & $0.68(0.50 \text { to } 0.92)^{*}$ & $0.91(0.77$ to 1.06$)$ \\
\hline Hay & $1.60(1.18 \text { to } 2.17)^{\star}$ & 0.77 (0.60to 0.98$)^{\star}$ & 1.07 (0.88 to 1.30$)$ \\
\hline Smidt & $2.86(1.96 \text { to } 4.16)^{*}$ & - & 0.84 (0.68 to1.02) \\
\hline Toker & $2.27(1.04$ to 4.97$)$ * & - & - \\
\hline Pooled & - & $0.66(0.53$ to 0.81$) *$ & $0.87(0.73$ to 1.04$)$ \\
\hline Heterogeneity & $>65 \%$ & $p=0.21,1^{2}=35 \%$ & $p=0.07,1^{2}=58 \%$ \\
\hline \multicolumn{4}{|c|}{ Pain (negative value favours treatment) SMD (95\% Cl) } \\
\hline \multicolumn{4}{|c|}{ CSI vs no intervention or NSAIDs } \\
\hline Bisset & $-1.43(-1.83 \text { to }-1.04)^{*}$ & $0.40(0.04 \text { to } 0.76)^{*}$ & $0.27(-0.08$ to 0.62$)$ \\
\hline Coombes & $-2.14(-2.68 \text { to }-1.60)^{*}$ & $0.16(-0.28$ to 0.59$)$ & $0.08(-0.35$ to 0.52$)$ \\
\hline Hay & $-1.05(-1.45 \text { to }-0.66)^{\star}$ & $0.42(0.04 \text { to } 0.80)^{*}$ & $1.35(0.94 \text { to } 1.76)^{*}$ \\
\hline Smidt & $-1.49(1.89 \text { to }-1.08)^{\star}$ & $0.27(-0.09$ to 0.63$)$ & $0.15(-0.20$ to 0.51$)$ \\
\hline Toker & $-1.14(-2.07 \text { to }-0.22)^{*}$ & - & - \\
\hline Pooled & $-1.43(-1.64 \text { to }-1.23)^{\star}$ & $0.32(0.13 \text { to } 0.51)^{*}$ & \\
\hline Heterogeneity & $p=0.032,\left.\right|^{2}=62 \%$ & $p=0.79,1^{2}=0 \%$ & $>65 \%$ \\
\hline \multicolumn{4}{|c|}{ CSI vs lidocaine injection } \\
\hline Lindenhovius & $-0.25(-0.74$ to 0.24$)$ & $0.27(-0.30$ to 0.84$)$ & - \\
\hline Price 1 & $-1.06(-1.63 \text { to }-0.49)^{*}$ & $3.13(2.31 \text { to } 3.95)^{*}$ & - \\
\hline Price 2 & $-3.37(-4.20 \text { to }-2.54)^{*}$ & $1.55(0.93 \text { to } 2.17)^{*}$ & \\
\hline Pooled & - & - & - \\
\hline Heterogeneity & $>65 \%$ & $>65 \%$ & - \\
\hline All above pooled & - & - & - \\
\hline Heterogeneity & $>65 \%$ & $>65 \%$ & - \\
\hline \multicolumn{4}{|c|}{ CSI, exercise and stretching vs exercise and stretching } \\
\hline Newcomert & $0.16(-0.49$ to 0.81$)$ & $-0.37(-1.04$ to 0.30$)$ & - \\
\hline \multicolumn{4}{|c|}{ Maximum grip strength (positive value favours treatment) SMD $(95 \% \mathrm{Cl})$} \\
\hline \multicolumn{4}{|c|}{ CSI vs no intervention or NSAIDs } \\
\hline Smidt & $-1.42(-1.82 \text { to }-1.03)^{*}$ & $-0.38(-0.74 \text { to }-0.02)^{*}$ & $-0.36(-0.72$ to 0.002$)$ \\
\hline No pooling & - & - & \\
\hline \multicolumn{4}{|c|}{ CSI vs lidocaine injection } \\
\hline Lindenhovius & $-0.19(-0.68$ to 0.30$)$ & $0.07(-0.50$ to 0.64$)$ & \\
\hline Price 1 & $-0.06(-0.59$ to 0.48$)$ & $-0.98(-1,58 \text { to }-0.38)^{*}$ & \\
\hline Price 2 & $2.31(1.62 \text { to } 3.00)^{*}$ & $-0.86(-1.44 \text { to }-0.29)^{*}$ & - \\
\hline Pooled & - & - & \\
\hline Heterogeneity & $>65 \%$ & $>65 \%$ & \\
\hline All above pooled & - & $-0.48(-0.73 \text { to }-0.24)^{*}$ & - \\
\hline Heterogeneity & $>65 \%$ & $p=0.04, I^{2}=64 \%$ & \\
\hline \multicolumn{4}{|c|}{ CSI, exercise and stretching vs exercise and stretching } \\
\hline Newcomer† & $-0.17(-0.61$ to 0.27$)$ & - & - \\
\hline
\end{tabular}

*Statistically significant $(p<0.05)$; Price 1: hydrocortisone versus lidocaine and change in pain-free grip strength and Price 2: triamcinolone versus lidocaine.

†The values for Newcomer are given as change in pain.

CSI, corticosteroid injection; NSAIDS, non-steroidal anti-inflammatory drugs; RR, relative risk; SMD, standard mean difference.

grip strength, we found moderate evidence of no significant difference. ${ }^{35}$ For corticosteroid injection versus lidocaine injection and corticosteroid injection, and exercise and stretching versus exercise and stretching alone, we found no data on the long-term effect.

\section{Physiotherapy}

We included five studies $(\mathrm{n}=600)$ investigating non-electrotherapeutical physiotherapy, representing five different treatment modalities (table 4 and figure $3^{52}$ ).
Two studies investigated the efficacy of manipulation and exercise versus no intervention. ${ }^{29}{ }^{38}$ In the short term, the pooled estimates showed a large positive effect on overall improvement. For pain, pooling was not possible due to heterogeneity. We found strong evidence for a beneficial effect, whereas for pain-free grip strength we found moderate evidence for a beneficial effect. In the intermediate term, the pooled estimates showed no difference between treatment and control for either pain or overall improvement. There 

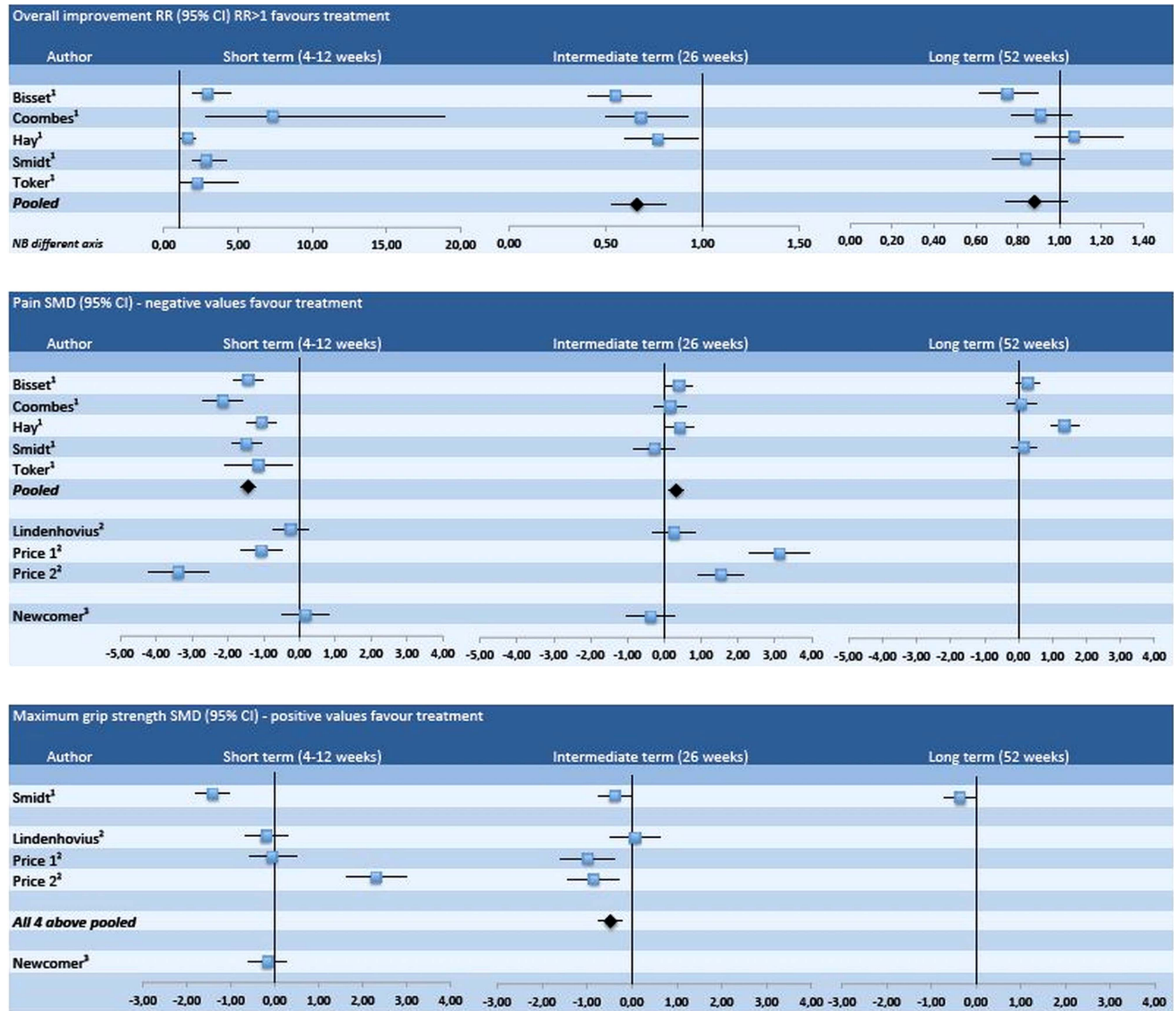

$R R$ : relative risk

Price 1: hydrocortisone vs lidocaine

$S M D$ : standardised mean difference

Price 2: triamcinolone vs lidocaine

1: Corticosteroid injection (CSI) vs no intervention or NSAIDs

2: CSI vs lidocaine injection

3: CSI, excercise and stretching vs excersise and stretching. The values for Newcomer are given as change in pain and chanqe in pain free grip strength.

Figure 2 Forest plot of effect sizes for corticosteroid injection.

was moderate evidence for no difference in pain-free grip strength. In the long term, the pooled estimates again showed no difference between treatment and control for either pain or improvement and we found moderate evidence for no difference in pain-free grip strength.

The efficacy of exercise versus no intervention was investigated in one study. ${ }^{40}$ We found moderate evidence for no short-term difference in effect for outcomes on pain and Disability of the Arm, Shoulder and Hand (DASH) score. There were no data on the intermediateterm or long-term effect.

For eccentric exercise and stretching versus stretching, investigated in one study, ${ }^{32}$ we found moderate evidence for no short-term treatment effect for outcomes on pain, pain-free grip strength and DASH score. There were no data on the intermediate-term or long-term effect.

The same study also investigated the efficacy of concentric exercise and stretching versus stretching. We found moderate evidence for no short-term treatment effect for outcomes on pain, pain-free grip strength and DASH score. There were no data on the intermediateterm or long-term effect.

Eccentric exercise with stretching versus no intervention was investigated in one study. ${ }^{41}$ We found moderate evidence for a positive effect on pain and grip strength at short-term follow-up. There were no data on efficacy at intermediate follow-up, but in the long term we found moderate evidence of a positive effect on overall improvement, pain and grip strength. 
Table 4 Effect sizes of treatment effects for non-electrotherapeutic physiotherapy

\begin{tabular}{|c|c|c|c|}
\hline & $\begin{array}{l}\text { Short term } \\
\text { 4-12 weeks }\end{array}$ & $\begin{array}{l}\text { Intermediate term } \\
26 \text { weeks }\end{array}$ & $\begin{array}{l}\text { Long term } \\
52 \text { weeks }\end{array}$ \\
\hline \multicolumn{4}{|c|}{ Manipulation and exercise vs no intervention } \\
\hline \multicolumn{4}{|c|}{ Overall improvement $\mathrm{RR}$ (relative risk) $(95 \% \mathrm{Cl})-\mathrm{RR}>1$ favours treatment } \\
\hline Bisset & $2.44(1.54 \text { to } 3.85)^{*}$ & $0.94(0.78$ to 1.12$)$ & $1.04(0.93$ to 1.15$)$ \\
\hline Coombes & $4.00(1.46 \text { to } 10.94)^{*}$ & $1.06(0.89$ to 1.28$)$ & 1.08 (0.99 to 1.18$)$ \\
\hline Pooled & $2.75(2.09 \text { to } 3.62)^{*}$ & $0.99(0.75$ to 1.30$)$ & 1.05 (0.75 to 1.49$)$ \\
\hline Heterogeneity & $p=0.37,1^{2}=0 \%$ & $p=0.331^{2}=0 \%$ & $\mathrm{p}=0.57 P^{2}=0 \%$ \\
\hline \multicolumn{4}{|c|}{ Pain SMD (standardised mean difference; $95 \% \mathrm{Cl}$ )-negative value favours treatment } \\
\hline Bisset & $-0.63(-0.99 \text { to }-0.27)^{\star}$ & $-0.25(-0.62$ to 0.11$)$ & $-0.38(-0.74 \text { to }-0.03)^{\star}$ \\
\hline Coombes & $-1.27(-1.74 \text { to }-0.79)^{\star}$ & $0.00(-0.44$ to 0.44$)$ & $0.00(-0.44$ to 0.44$)$ \\
\hline Pooled & - & $-0.15(-0.43$ to 0.13$)$ & $-0.23(--0.51$ to 0.04$)$ \\
\hline Heterogeneity & $>65 \%$ & $p=0.39 l^{2}=0 \%$ & $\mathrm{p}=0.18 P^{2}=45 \%$ \\
\hline \multicolumn{4}{|c|}{ Pain-free grip strength ratio affected/ unaffected arm SMD (95\%) } \\
\hline Bisset & $0.76(0.39 \text { to } 1.13)^{*}$ & $0.20(-0.47$ to 0.56$)$ & $0.17(-0.18$ to 0.52$)$ \\
\hline \multicolumn{4}{|c|}{ Exercise vs no intervention } \\
\hline \multicolumn{4}{|c|}{ DASH score (0-100, 100 most discomforts, negative value favours treatment) SMD (95\% Cl) } \\
\hline Peterson & $-0.03(-0.47$ to 0.40$)$ & - & \\
\hline \multicolumn{4}{|c|}{ Pain on maximum voluntary contraction SMD $(95 \% \mathrm{Cl})$-negative value favours treatment } \\
\hline Peterson & $-0.30(-0.74$ to 0.14$)$ & - & \\
\hline \multicolumn{4}{|c|}{ Pain on maximum muscular elongation SMD $(95 \% \mathrm{Cl})$-negative value favours treatment } \\
\hline Peterson & $-0.24(-0.68$ to 0.19$)$ & - & \\
\hline \multicolumn{4}{|c|}{ Eccentric exercise and stretching vs stretching } \\
\hline \multicolumn{4}{|c|}{ DASH score (0-100, 100 most discomforts, negative value favours treatment) SMD (95\% Cl) } \\
\hline M-Silvestrini & $-0.07(-0.46$ to 0.60$)$ & - & \\
\hline \multicolumn{4}{|c|}{ Pain SMD $(95 \% \mathrm{Cl})$-negative value favours treatment } \\
\hline M-Silvestrini & $-0.04(-0.57$ to 0.49$)$ & - & \\
\hline \multicolumn{4}{|c|}{ Pain-free grip strength affected arm SMD (95\%) } \\
\hline M-Silvestrini & $-0.26(-0.79$ to 0.27$)$ & - & \\
\hline \multicolumn{4}{|c|}{ Concentric exercise and stretching vs stretching } \\
\hline \multicolumn{4}{|c|}{ DASH score (0-100, 100 most complaints, negative value favours treatment) SMD (95\% Cl) } \\
\hline M-Silvestrini & $0.14(-0.39$ to 0.68$)$ & - & \\
\hline \multicolumn{4}{|c|}{ Pain SMD $(95 \% \mathrm{CI})$-negative value favours treatment } \\
\hline M-Silvestrini & $0.41(-0.13$ to 0.95$)$ & - & \\
\hline \multicolumn{4}{|c|}{ Pain-free grip strength affected arm SMD $(95 \% \mathrm{Cl})$} \\
\hline M-Silvestrini & $-0.34(-0.88$ to 0.20$)$ & & \\
\hline \multicolumn{4}{|c|}{$\begin{array}{l}\text { Eccentric exercise and stretching vs no intervention (sham ultrasound, elbow support) overall improvement } \mathrm{RR}(95 \% \mathrm{Cl}) \text { - } \\
\mathrm{RR}>1 \text { favours treatment }\end{array}$} \\
\hline Selvanetti & - & - & $23.39(3.38 \text { to } 161.70)^{*}$ \\
\hline \multicolumn{4}{|c|}{ Pain on Ko scale (larger value means less pain) SMD (95\% CI) } \\
\hline Selvanetti & $4.45(3.51 \text { to } 5.40)^{*}$ & & -4.65 (3.68 to 5.63$)$ * \\
\hline \multicolumn{4}{|c|}{ Grip strength on Ko scale (larger value means greater strength) SMD $(95 \% \mathrm{Cl})$} \\
\hline Selvanetti & $3.16(2.40 \text { to } 3.92)^{*}$ & & $-3.65(2.82$ to 4.47$)$ * \\
\hline
\end{tabular}

\section{DISCUSSION}

Summary of main results

This review found overall evidence for a short-term beneficial effect of corticosteroid injection. At intermediate follow-up, the evidence showed an overall negative effect. For corticosteroid injection versus lidocaine injection, we found the evidence to be conflicting. At long-term follow-up, the evidence suggests no difference in effect on overall improvement and grip strength, but the evidence was conflicting for pain. For manipulation and exercise versus no intervention, we found an overall beneficial effect in the short term, but there was no significant difference at intermediate-term or long-term follow-up. The evidence on exercise versus no intervention showed no differences at short-term follow-up. For eccentric exercise and stretching versus stretching alone, the evidence showed no short-term difference in effect. The same was found for concentric exercise and stretching versus stretching. The evidence on eccentric exercise and stretching versus no intervention showed a beneficial effect in the short term and long term, while there were no data on intermediate follow-up.

For treating lateral epicondylitis, this review showed evidence for a short-term benefit of corticosteroid injection and manipulation with exercise. Eccentric exercise and stretching showed beneficial effect both at shortterm and long-term follow-up. 

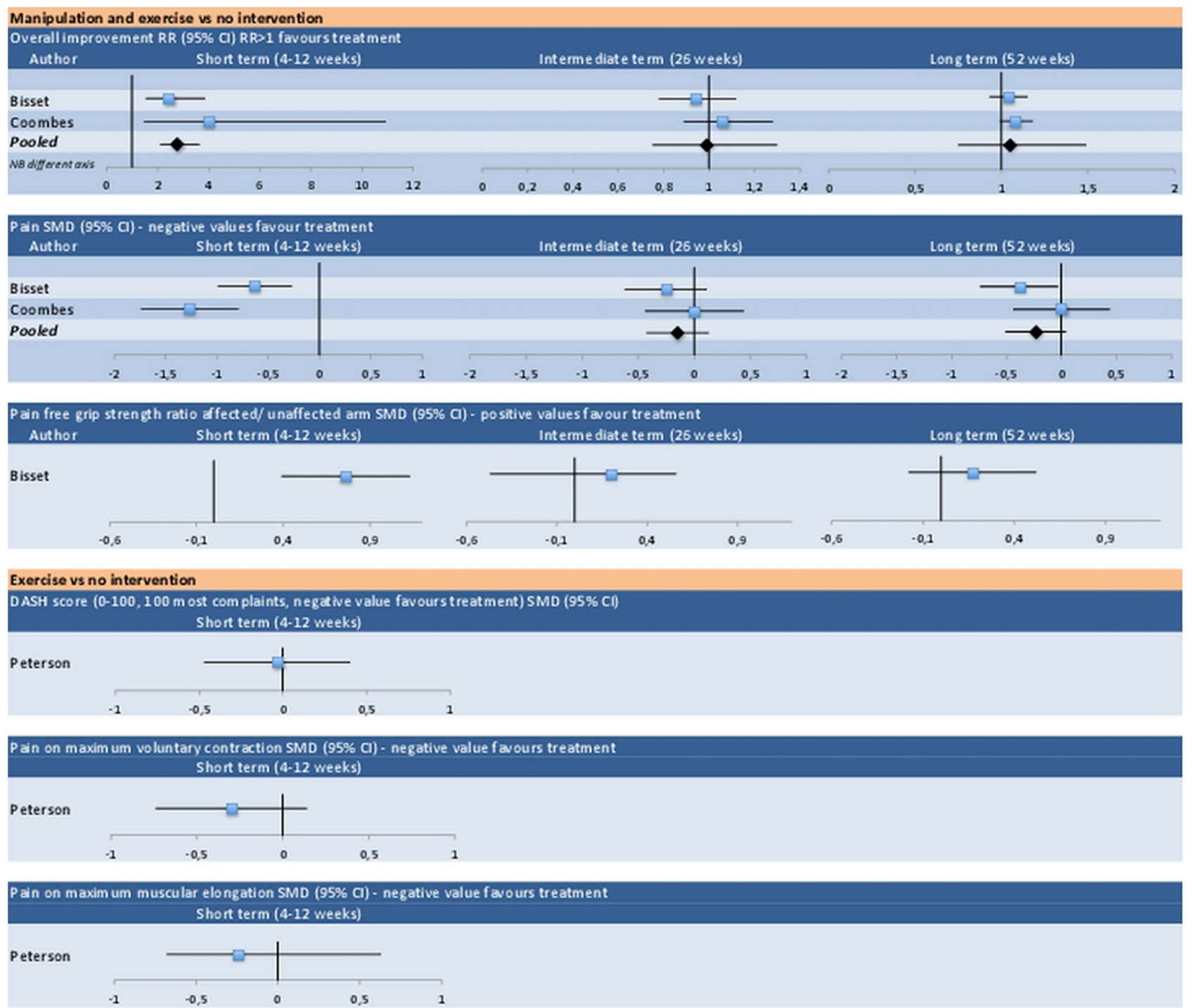

Figure 3 Forest plot of effect sizes for non-electrotherapeutic physiotherapy.

\section{Overall completeness and quality of the evidence}

There is a paucity of well-designed studies for determining the effect of non-electrotherapeutic physiotherapy. The conclusions on the effect of these treatments are therefore limited. It was possible to do a comparison and review of several individual studies for only one treatment modality, manipulation and exercise versus no intervention (table 4).

We included eight studies treating a total of 925 patients with corticosteroid injections in our review. The conclusions for this treatment are more solid due to the larger number of studies, seven of which had long-term follow-up. Owing to differences in the type of corticosteroids used, treatment regimes and outcome measures in the included studies, pooling of outcome measures was difficult. We found statistical heterogeneity for most outcomes, and pooling was possible only for a few of the outcomes and follow-ups. The long-term effect of corticosteroid injection showed conflicting results in the included studies. The large differences across studies in the duration of complaints at baseline, corticosteroids used in different dosages and control group treatments may explain this.

The difference in the duration of complaints at baseline complicates the interpretation and comparison of the results, since there might be different effects of the treatments on an epicondylitis of recent onset compared with one that has lasted several months. This is also reflected by Cook and Purdam ${ }^{53}$ who considered tendinopathy as a continuum with three stages and different characteristics and presumably treatments for each stage. Haahr and Andersen ${ }^{54}$ found that high physical strain at work, work with manual tasks, high perceived stress at baseline and a high level of pain and dysfunction seem to predict an unfavourable outcome after 1 year. Thus, any differences in baseline characteristics for these parameters might possibly influence between-group differences of outcome. 

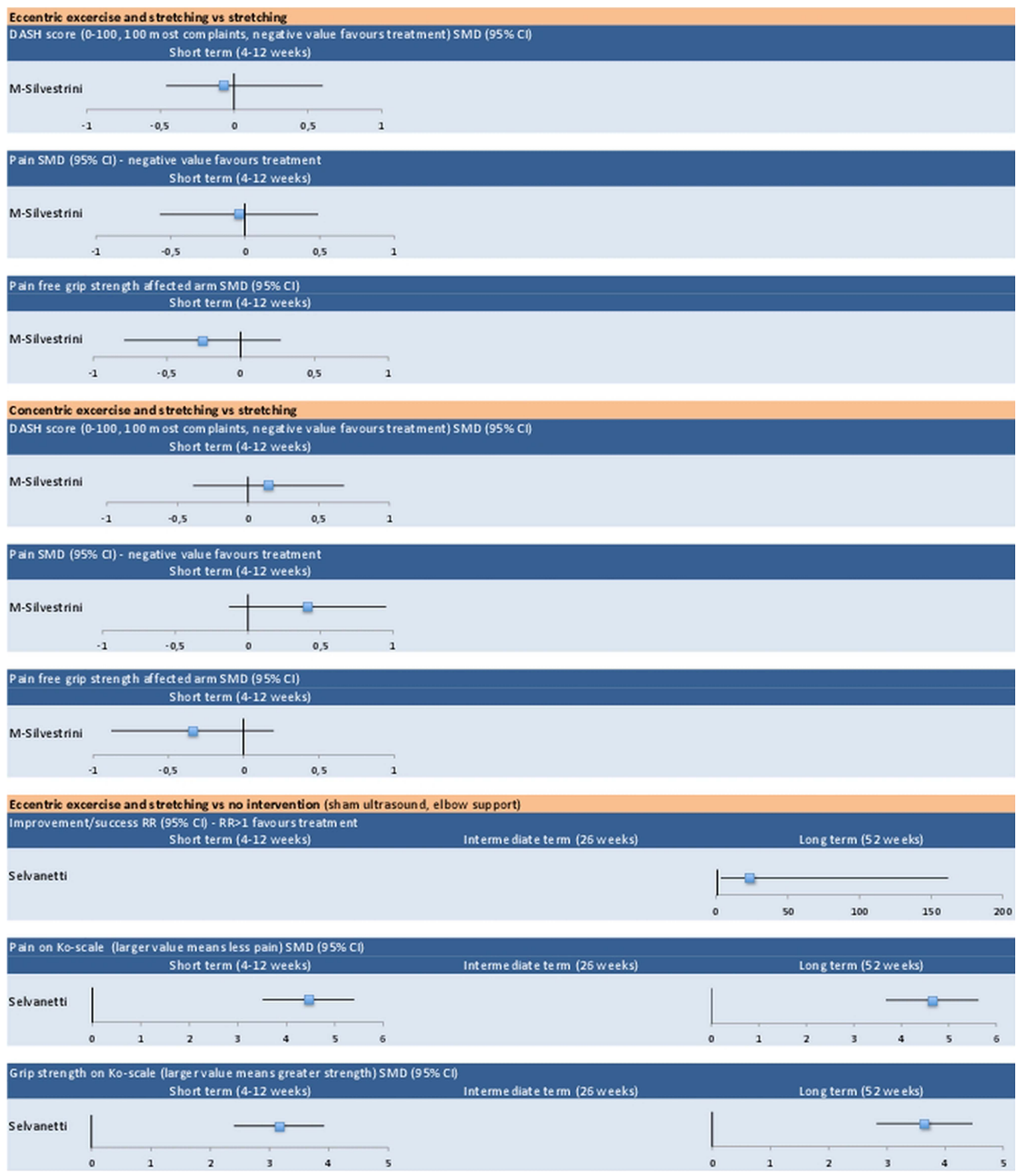

Figure 3 (Continued)

\section{Potential biases in the review process}

The search process, selection of search terms and possible errors in reading and assessing the large number of articles represent a possible bias. Although we have searched several databases with a number of search terms, we may have missed some published studies. To reduce the risk of bias in the inclusion process, we used two reviewers who independently screened the articles.

Our choice of inclusion criteria, especially the type of control or comparison treatment and the use of a cut-off quality score (PEDro), has important implications for the conclusions that can be drawn from this review. The efficacy of the treatments are here compared only with a 
control (no treatment) or to an underlying treatment that is common to both intervention groups, so no conclusion can be drawn as to which of the two different treatments is better.

To address the issue of publication bias, we searched two clinical trial registries: ClinicalTrial.gov (US National Institutes of Health) and Current Clinical Trials. We found no completed, unpublished studies on corticosteroid injection. Two completed studies on non-electrotherapeutic physiotherapy were found, one from the UK completed in 2008 on manipulation with movement and one from Sweden completed in 2009 on eccentric training. We have found no published articles from these studies. Unpublished studies are not indexed in PubMed or other databases, and older studies may have been conducted without registration in a clinical trial registry, making it difficult to make an overall assessment of publication bias.

\section{Agreements and disagreements with other reviews}

Our findings agree with earlier reviews. ${ }^{14} 16 \quad 17 \quad 55$ We found consistent evidence of a beneficial short-term effect of corticosteroid injections, but evidence on the long-term effect is still conflicting. Coombes et $a l^{15}$ found in their review that corticosteroid injections have a worse outcome in the long term than most conservative interventions for tendinopathies of different locations. The included studies in our review did not allow for a similar strong conclusion on the long-term effect of corticosteroid injections. For non-electrotherapeutical physiotherapy, we agree with earlier reviews ${ }^{14} \quad 16181921$ that there is moderate evidence of a short-term effect of manipulation and exercise. Our review strengthens this conclusion with the inclusion of a recently published study. ${ }^{40}$ In addition, we found moderate evidence of the short-term and long-term beneficial effects of eccentric exercise and stretching.

\section{AUTHORS' CONCLUSIONS Implications for practice}

We found that corticosteroid injection and manipulation with exercise gave a short-term benefit compared with control for treating lateral epicondylitis. In the intermediate term, treatment with corticosteroid injection came out worse, while manipulation with exercise was not different from control. In the long term, both treatments showed no benefit over control. For patients wanting treatment, it seems reasonable to recommend manipulation and exercise. For patients with mild symptoms, a wait-and-see approach would be appropriate. Though showing a large short-term benefit, the negative intermediate-term effect and uncertain long-term effect of corticosteroid injection make this treatment difficult to recommend. Eccentric exercise with stretching showed efficacy both at short-term and long-term follow-up, but only in one study.

\section{Implications for research}

We found few studies and some conflicting results on the long-term efficacy of corticosteroid injection. More trials or a meta-analysis with individual patient data from earlier studies might give better answers to the question on the long-term effect.

For non-electrotherapeutical physiotherapy, more studies with a randomised controlled design are needed. Blinding, for example by using a blinded assessor, should be applied wherever possible. The promising results of manipulation with exercise and eccentric exercise with stretching need further investigation.

Future studies should differentiate between acute and chronic complaints. Baseline levels of perceived pain, stress levels, handedness and presence of physical stress at work should be recorded. Standardisation in the usage of outcome measures will enable data pooling and meta-analyses in future reviews. Studies investigating the combined effect of physiotherapy and corticosteroid injection treatments would also be useful. Most patients with acute lateral epicondylitis are treated in a general practice setting, and future research should be performed in such a setting.

Contributors $\mathrm{MO}$ and $\mathrm{OH}$ designed the study, performed the searches, read the articles, decided which articles to include, performed the data extractions, interpreted the findings and wrote the main manuscript. $\mathrm{ML}$ designed the study, decided which articles to include, interpreted the findings and revised the manuscript. SB decided which articles to include, interpreted the findings and revised the manuscript. HS did the statistical calculations and analysis, interpreted the findings and revised the manuscript.

Funding Our work was funded by The Fund for General Practice Research, The Norwegian Medical Association, Oslo, Norway.

Competing interests None.

Provenance and peer review Not commissioned; externally peer reviewed.

Data sharing statement No additional data are available.

Open Access This is an Open Access article distributed in accordance with the Creative Commons Attribution Non Commercial (CC BY-NC 3.0) license, which permits others to distribute, remix, adapt, build upon this work noncommercially, and license their derivative works on different terms, provided the original work is properly cited and the use is non-commercial. See: http:// creativecommons.org/licenses/by-nc/3.0/

\section{REFERENCES}

1. Chard MD, Hazleman BL. Tennis elbow-a reappraisal. $\mathrm{Br} J$ Rheumatol 1989;28:186-90.

2. Hamilton PG. The prevalence of humeral epicondylitis: a survey in general practice. J R Coll Gen Pract 1986;36:464-5.

3. Kivi P. The etiology and conservative treatment of humeral epicondylitis. Scand J Rehabil Med 1983;15:37-41.

4. Hudak PL, Cole DC, Haines AT. Understanding prognosis to improve rehabilitation: the example of lateral elbow pain. Arch Phys Med Rehabil 1996;77:586-93.

5. Murtagh J. Tennis elbow. Aust Fam Physician 1984;13:51.

6. Torp-Pedersen TE, Torp-Pedersen ST, Qvistgaard E, et al. Effect of glucocorticosteroid injections in tennis elbow verified on colour Doppler ultrasonography: evidence of inflammation. Br J Sports Med 2008;42:978-82.

7. Alfredson $\mathrm{H}$, Lorentzon R. Chronic tendon pain: no signs of chemical inflammation but high concentrations of the neurotransmitter glutamate. Implications for treatment? Curr Drug Targets 2002;3:43-54. 
8. Pattanittum P, Turner T, Green S, et al. Non-steroidal anti-inflammatory drugs (NSAIDs) for treating lateral elbow pain in adults. Cochrane Database Syst Rev 2013;5:CD003686.

9. Buchbinder R, Green S, Youd JM, et al. Shock wave therapy for lateral elbow pain. Cochrane Database Syst Rev 2005;4:CD003524.

10. Green S, Buchbinder R, Barnsley L, et al. Acupuncture for lateral elbow pain. Cochrane Database Syst Rev 2002;1:CD003527.

11. Brosseau L, Casimiro L, Milne S, et al. Deep transverse friction massage for treating tendinitis. Cochrane Database Syst Rev 2002;4:CD003528

12. Struijs PA, Smidt $\mathrm{N}$, Arola $\mathrm{H}$, et al. Orthotic devices for the treatment of tennis elbow. Cochrane Database Syst Rev 2001;2:CD001821.

13. Buchbinder R, Green S, Bell SN, et al. Surgery for lateral elbow pain. Cochrane Database Syst Rev 2011;3:CD003525.

14. Barr S, Cerisola FL, Blanchard V. Effectiveness of corticosteroid injections compared with physiotherapeutic interventions for lateral epicondylitis: a systematic review. Physiotherapy 2009;95:251-65.

15. Coombes BK, Bisset L, Vicenzino B. Efficacy and safety of corticosteroid injections and other injections for management of tendinopathy: a systematic review of randomised controlled trials. Lancet 2010;376:1751-67.

16. Nimgade A, Sullivan M, Goldman R. Physiotherapy, steroid injections, or rest for lateral epicondylosis? What the evidence suggests. Pain Pract 2005;5:203-15.

17. Smidt N, Assendelft WJ, Van der Windt DA, et al. Corticosteroid injections for lateral epicondylitis: a systematic review. Pain 2002;96:23-40.

18. Bisset L, Paungmali A, Vicenzino B, et al. A systematic review and meta-analysis of clinical trials on physical interventions for lateral epicondylalgia. Br J Sports Med 2005;39:411-22.

19. Herd CR, Meserve BB. A systematic review of the effectiveness of manipulative therapy in treating lateral epicondylalgia. J Man Manip Ther 2008;16:225-37.

20. Smidt N, Assendelft WJ, Arola $\mathrm{H}$, et al. Effectiveness of physiotherapy for lateral epicondylitis: a systematic review. Ann Med 2003;35:51-62.

21. Trudel D, Duley J, Zastrow I, et al. Rehabilitation for patients with lateral epicondylitis: a systematic review. $J$ Hand Ther 2004:17:243-66.

22. van Tulder MW, Suttorp M, Morton S, et al. Empirical evidence of an association between internal validity and effect size in randomized controlled trials of low-back pain. Spine (Phila Pa 1976) 2009;34:1685-92

23. Juni P, Altman DG, Egger M. Systematic reviews in health care: assessing the quality of controlled clinical trials. $B M J$ 2001;323:42-6.

24. Higgins J, Green S. Cochrane handbook for systematic reviews of interventions version 5.0.2. The Cochrane Collaboration, 2009.

25. Moher D, Schulz KF, Altman DG. The CONSORT statement: revised recommendations for improving the quality of reports of parallel-group randomised trials. Lancet 2001;357:1191-4.

26. Verhagen AP, de Vet HC, de Bie RA, et al. The Delphi list: a criteria list for quality assessment of randomized clinical trials for conducting systematic reviews developed by Delphi consensus. J Clin Epidemiol 1998;51:1235-41.

27. Maher CG, Sherrington C, Herbert RD, et al. Reliability of the PEDro scale for rating quality of randomized controlled trials. Phys Ther 2003;83:713-21.

28. Moher D, Pham B, Jones A, et al. Does quality of reports of randomised trials affect estimates of intervention efficacy reported in meta-analyses? Lancet 1998;352:609-13.

29. Bisset L, Beller E, Jull G, et al. Mobilisation with movement and exercise, corticosteroid injection, or wait and see for tennis elbow: randomised trial. BMJ 2006;333:939.

30. Hay EM, Paterson SM, Lewis M, et al. Pragmatic randomised controlled trial of local corticosteroid injection and naproxen for treatment of lateral epicondylitis of elbow in primary care. $B M J$ 1999;319:964-8.

31. Lindenhovius A, Henket M, Gilligan BP, et al. Injection of dexamethasone versus placebo for lateral elbow pain: a prospective, double-blind, randomized clinical trial. J Hand Surg Am Vol 2008;33:909-19.

32. Martinez-Silvestrini JA, Newcomer KL, Gay RE, et al. Chronic lateral epicondylitis: comparative effectiveness of a home exercise program including stretching alone versus stretching supplemented with eccentric or concentric strengthening. J Hand Ther 2005;18:411-9, quiz.

33. Newcomer KL, Laskowski ER, Idank DM, et al. Corticosteroid injection in early treatment of lateral epicondylitis. Clin J Sport Med 2001;11:214-22.

34. Price $\mathrm{R}$, Sinclair $\mathrm{H}$, Heinrich $\mathrm{I}$, et al. Local injection treatment of tennis elbow-hydrocortisone, triamcinolone and lignocaine compared. Br J Rheumatol 1991;30:39-44.

35. Smidt N, Van der Windt DA, Assendelft WJ, et al. Corticosteroid injections, physiotherapy, or a wait-and-see policy for lateral epicondylitis: a randomised controlled trial. Lancet 2002;359:657-62

36. Toker S, Kilincoglu V, Aksakalli E, et al. Short-term results of treatment of tennis elbow with anti-inflammatory drugs alone or in combination with local injection of a corticosteroid and anesthetic mixture. Acta Orthop Traumatol Turcica 2008;42:184-7.

37. Tonks JH, Pai SK, Murali SR. Steroid injection therapy is the best conservative treatment for lateral epicondylitis: a prospective randomised controlled trial. Int J Clin Pract 2007;61:240-6.

38. Coombes BK, Bisset L, Brooks $\mathrm{P}$, et al. Effect of corticosteroid injection, physiotherapy, or both on clinical outcomes in patients with unilateral lateral epicondylalgia: a randomized controlled trial. JAMA 2013;309:461-9.

39. Kochar M, Dogra A. Effectiveness of a specific physiotherapy regimen on patients with tennis elbow: clinical study. Physiotherapy 2002;88:333-41.

40. Peterson M, Butler S, Eriksson M, et al. A randomized controlled trial of exercise versus wait-list in chronic tennis elbow (lateral epicondylosis). Ups J Med Sci 2011;116:269-79.

41. Selvanetti A, Barrucci A, Antonaci $A$, et al. Role of the eccentric exercise in the functional reeducation of lateral epicondylitis: a randomised controlled clinical trial. Medicina dello Sport 2003:56:103-13.

42. Higgins JP, Thompson SG, Deeks JJ, et al. Measuring inconsistency in meta- analyses. BMJ 2003;327:557-60.

43. van Tulder M, Furlan A, Bombardier C, et al. Updated method guidelines for systematic reviews in the cochrane collaboration back review group. Spine 2003;28:1290-9.

44. Shrout PE, Fleiss JL. Intraclass correlations: uses in assessing rater reliability. Psychol Bull 1979;86:420-8.

45. Altay T, Gunal I, Ozturk H. Local injection treatment for lateral epicondylitis. Clin Orthop Relat Res 2002;398:127-30.

46. Croisier JL, Foidart-Dessalle $\mathrm{M}$, Tinant $\mathrm{F}$, et al. An isokinetic eccentric programme for the management of chronic lateral epicondylar tendinopathy. Br J Sports Med 2007;41:269-75.

47. Dogramaci Y, Kalaci A, Savas N, et al. Treatment of lateral epicondilitis using three different local injection modalities: a randomized prospective clinical trial. Arch Orthop Trauma Surg 2009;129:1409-14.

48. Paungmali A, O'Leary S, Souvlis $\mathrm{T}$, et al. Hypoalgesic and sympathoexcitatory effects of mobilization with movement for lateral epicondylalgia. Phys Ther 2003;83:374-83.

49. Saartok T, Eriksson E. Randomized trial of oral naproxen or local injection of betamethasone in lateral epicondylitis of the humerus. Orthopedics 1986;9:191-4.

50. Vicenzino B, Paungmali A, Buratowski S, et al. Specific manipulative therapy treatment for chronic lateral epicondylalgia produces uniquely characteristic hypoalgesia. Man Ther 2001;6:205-12.

51. Viswas R, Ramachandran R, Korde Anantkumar P. Comparison of effectiveness of supervised exercise program and Cyriax physiotherapy in patients with tennis elbow (lateral epicondylitis): a randomized clinical trial. Sci World J 2012;012:939645.

52. Neyeloff JL, Fuchs SC, Moreira LB. Meta-analyses and forest plots using a microsoft excel spreadsheet: step-by-step guide focusing on descriptive data analysis. BMC Res Notes 2012;5:52.

53. Cook JL, Purdam CR. Is tendon pathology a continuum? A pathology model to explain the clinical presentation of load-induced tendinopathy. Br J Sports Med 2009;43:409-16.

54. Haahr JP, Andersen JH. Prognostic factors in lateral epicondylitis: a randomized trial with one-year follow-up in 266 new cases treated with minimal occupational intervention or the usual approach in general practice. Rheumatology (Oxford) 2003;42:1216-25.

55. Gaujoux-Viala C, Dougados M, Gossec L. Efficacy and safety of steroid injections for shoulder and elbow tendonitis: a meta-analysis of randomised controlled trials. Ann Rheum Dis 2009;68:1843-9. 